УДК 347.734

DOI https://doi.org/10.32838/TNU-2707-0581/2021.1/16

\title{
Хачатурян В.X.
}

Навчально-науковий юридичний інститут

Київського міжнародного університету

\section{Хачатурян T.X.}

Київський міжнародний університет

\section{ПРО ВИНИКНЕННЯ ТА ІСТОРІЮ ПРАВОВОГО РЕГУЛЮВАННЯ БАНКІВСЬКОЇ ДІЯЛЬНОСТІ УКРАЇНИ}

Стаття присвячена дослідженню та розвитку банківської діяльності з дня незалежності України. Проблема зміцнення і розвитку банківської системи повинна завжди перебувати у центрі уваги держави і суспільства, позаяк від ӥх ефективного вирімення залежить не тільки стан банківського сектору, його здатність виконувати властиві йому унікальні функиії, а також стійкість і безпека фінансової системи крайни загалом. 3 огляду на пряму залежність фінансової системи держави від банківської системи, можна стверджувати, що в умовах світової фінансової кризи питання ефективного правового управління банківською діяльністю стає особливо актуальним.

Регулювання банківської діяльності особливо специфічне, оскільки воно уявлясться як прочес встановлення правил здійснення банківської діяльності в порядку законодавчої та іншої нормотворчої діяльності. Органи всіх гілок влади контролюють Національний банк Украӥни, останній здійснює контроль $і$ нагляд за дотриманням банківського законодавства комериійними банками та іншими небанківськими фінансово-кредитними інститутами, застосовує примус у разі допущення порушень встановлених правил поведінки поряд із судовою владою. Цілі державної політики у правовій сфері визначають ијілі системи державного управління в такій сфері, як забезпечення стабільності та розвитку держави. Саме через історію розвитку можна дійти остаточного висновку.

Отже, це дослідження присвячене вивченню правових основ банківської системи Украӥни. Розгляд проблем становлення і розвитку банківської системи та ї̈ правового регулювання тема надзвичайно иікава й актуальна.

Проведена в Україні економічна реформа спрямована на змічнення фундаменту правової держави та інститутів громадянського суспільства. Органічною складовою частиною иієї реформи є банківська реформа, щзо спрямована на створення ефективної банківської системи, відповідної економіці ринкового типу $і$ адекватного банківського законодавства. Стан банківської системи - один з найважливіших показників стану всієї економіки краӥни. У наукових джерелах влучно виділяються такі етапи розвитку банківської системи Украӥни.

Ключові слова: Закон Украӥни «Про банки та банківську діяльність», Національний банк України, банківська система.

Постановка проблеми. Банківська діяльність має актуальну для сучасного суспільства тему. Адже банківська діяльність України виступає невід'ємною складовою частиною сучасної системи управління на шляху до правової держави. В Україні норми національного законодавства у цій сфері містять чимало колізій та прогалин, а тому безперечно потребують вдосконалення.

Робота мала на меті вивчення правового регулювання банківської діяльності в Україні, дослідження проблемних питань, узагальнення та формування теоретичних положень та практичних висновків у цій сфері. Проблема зміцнення і розвитку банківської системи перебуває в центрі уваги держави і суспільства, позаяк від їх ефективного вирішення залежить не тільки стан банківського сектору, його здатність виконувати властиві йому унікальні функції, а також стійкість і безпека фінансової системи країни загалом. 3 огляду на пряму залежність фінансової системи держави від банківської системи можна стверджувати, що в умовах світової фінансової кризи питання ефективного правового управління банківською діяльністю стає особливо актуальним. 
Аналіз останніх досліджень і публікацій. Вивченню цієї проблематики присвячено праці таких учених, як: В. Тичина, О. Орлюк, Я. Грудзевич, В. Міщенко, П. Нікіфоров, С. Очкуренко та ін. Їхні наукові напрацювання $є$ теоретикометодологічним підгрунтям для подальших наукових досліджень.

Формулювання цілей статті. Головне завдання - розглянути та проаналізувати історію правового регулювання банківської діяльності в Україні.

I етап (1988-1992 pp.) - початковий розвиток банківського сектору України. Характеризується прийняттям Закону України «Про банки та банківську діяльність», стихійним розвитком, постійною зміною суб'єктів конкурентного середовища та нормативно-правового регулювання банківської діяльності.

II етап (1993-1994 рр.) характеризується значною недовірою до банківських установ. Головним стратегічним орієнтиром банків було утримання позиції на ринку шляхом збільшення обігу коштів, максимального залучення вкладів від клієнтів.

III етап (1995-2001рp.) - поступовий розвиток банківської системи та поява банків з іноземним капіталом. Прийняття нової редакції Закону України «Про банки та банківську діяльність». Впровадження нових технологій та послуг.

IV етап (2001-2007 pp.) - бурхливий розвиток банківського сектору. Активізація процесів глобалізації фінансового сектору України. Стимулювання консолідації та укрупнення вітчизняного банківського капіталу.

V етап (кінець 2007 р. - початок 2009 р.) стрімке зниження обсягів розвитку банківських установ України. Поширення кризових явищ та збільшення рівня недовіри до банківської системи. Збільшення мінімального розміру статутного капіталу до 10 млн євро.

VI етап (з початку 2009 р. - до сьогодення) - підвищення вимог до діяльності вітчизняних банків. Дотримання банківськими установами стабілізаційних економічних нормативів КМУ. Передбачено створення санаційного банку [1, с. 24].

Кожен 3 цих етапів детермінував особливості розвитку правового регулювання банківської діяльності, оскільки наведені періоди характеризувалися якісною та кількісною характеристикою змін ролі банківської діяльності в економічній системі держави. Крім цього, на кожному етапі приймалися відповідні закони та підзаконні акти, що містили норми адміністративного права, покликані врегулювати банківську діяльність. Зазна- чимо, що наявні й інші погляди на періодизацію розвитку банківської системи України, проте не будемо детально їх аналізувати. Зазначимо лише, що становлення та розвиток банківської системи в кожен конкретний період характеризувалися своїми особливостями, які викликали необхідність в адміністративно-правовому регулюванні досліджуваної сфери.

Так, 20.03.1991 р. було прийнято Закон УРСР «Про банки і банківську діяльність» [4], введений в дію Постановою Верховної Ради УРСР «Про порядок введення в дію Закону України «Про банки і банківську діяльність». Цим Законом встановлено правовий статус та початкові повноваження центрального банку - Національного банку України, до яких входило регулювання банківської системи, ліцензійно-дозвільні функції та низка інших адміністративно-владних повноважень. Відповідні норми започаткували існування банківської системи як чітко визначеного інституту та адміністративно-правового регулювання банківської діяльності.

Важливим документом, який містить норми адміністративно-правового регулювання банківської діяльності, $є$ «Положення про порядок формування і розмір страхових фондів комерційних банків», затверджене постановою Правління НБУ № 167 від 30 червня 1995 року [9], що введене 3 метою підвищення надійності та стабільності банківської системи України, захисту кредиторів та вкладників комерційних банків. В його основу було закладено основні принципи нагляду, які були сформульовані Базельською угодою щодо банківського регулювання. 31 січня 1996 року Правлінням НБУ було видано постанову № 20, згідно 3 якою формування резервів стало обов'язковим для банків, а порушення цього правила мало наслідком притягнення до відповідальності [5].

Також було удосконалено у 1998 році адміністративно-правове регулювання видачі банківських ліцензій шляхом прийняття нового «Положення про порядок видачі банкам ліцензії на здійснення банківських операцій», затвердженого постановою НБУ від 06.05.98 № 181 [8]. Крім цього, у «Положенні про планування виїзних інспекцій» та «Положенні про порядок визначення та застосування комплексної рейтингової оцінки комерційних банків за системою CAMEL», що були затверджені постановою Правління НБУ від 25.06.98 № 246, були врегульовані питання щодо проведення інспекційних перевірок [6]. Таким чином, можна зробити висновок про формування цілісної системи адміністративно-правового регу- 
лювання банківської діяльності, яка охоплює весь спектр правовідносин у сфері здійснення такої діяльності. Ключовим та переломним фактором щодо адміністративно-правового регулювання банківської діяльності було прийняття Закону України «Про Національний банк України» від 20.05.1999 року [7]. Саме з цією подією багато вчених обгрунтовано пов'язують якісно новий період розвитку банківської системи. Це стосується, на нашу думку, і системи адміністративноправового регулювання банківської діяльності. 3 цього моменту відбувається оновлення підзаконних адміністративно-правових актів, що регулюють досліджувану діяльність. Варто відзначити перехід до якісно нової, більш сучасної та гнучкої системи адміністративно-правового регулювання банківської діяльності.

Також ключовим у сфері адміністративно-правового регулювання було прийняття нової редакції Закону України «Про банки і банківську діяльність». О.П. Орлюк твердить, що за допомогою вказаного Закону вдалося вирішити низку проблем щодо приведення вітчизняного банківського законодавства у відповідність до європейських стандартів [3, с. 32].

Не менш важливим для банківської системи було прийняття у вересні 2001 року Закону України «Про фонд гарантування вкладів фізичних осіб» [12], який піднімав рівень довіри до банківської системи та згодом набув окремих функцій щодо здійснення регулювання банківської діяльності. Цей Закон мав неабиякий позитивний вплив на розвиток банківської діяльності. Також помітну роль у регулюванні банківської діяльності відіграв Закон України «Про фінансові послуги та державне регулювання ринків фінансових послуг» [13]. Останній встановлював загальні положення щодо надання фінансових послуг, особливим видом яких $є$ банківські послуги. Проте станом натепер суто банківська діяльність не підпадає під правове регулювання вказаного Закону.

Висновки. Основною тенденцією цього періоду $є$ якісне удосконалення вже наявної нормативно-правової бази, оптимізація системи адміністративно-правового регулювання банківської діяльності та запозичення позитивного досвіду. Здебільшого відповідна нормотворчість була спрямована на забезпечення зростання та розвитку банківської системи, ії питомої ваги у економічній системі держави.

До цієї тенденції цільової спрямованості адміністративно-правового регулювання внесла корективи глобальна фінансова криза 2008 року. 3 цим моментом науковці пов'язують початок нового періоду у здійсненні банківської діяльності [2, с. 85]. Погоджуємось 3 тим, що цільова спрямованість адміністративно-правового регулювання банківської діяльності зазнала змін і основним завданням відповідного державного регулювання стало не розширення банківської системи, а ії стабілізація. Це відобразилося в якісних змінах законодавства 3 цього приводу. Наприклад, втратив чинність Закон України «Про Фонд гарантування вкладів фізичних осіб» у зв'язку з набуттям чинності новим Законом України «Про систему гарантування вкладів фізичних осіб» [10], яким чітко визначені повноваження Фонду та порядок здійснення ним регулювання банківської діяльності. Таким чином, можна зазначити, що система нормативно-правового регулювання почала змінюватися задля того, щоб забезпечити стабільність банківської системи та надання банківських послуг.

Визначено банківський нагляд в Україні як систему контролю та активних впорядкованих дій НБУ, спрямованих на забезпечення дотримання банками та іншими особами, стосовно яких НБУ здійснює наглядову діяльність, законодавства України і встановлених нормативів з метою забезпечення стабільності банківської системи тазахистуінтересіввкладників такредиторівбанку.

Розвинуто тезу про те, що необхідність регулювання діяльності банків $є$ важливим не тільки на національному рівні, але також і на міжнародному рівні. На національному рівні необхідність регулювання полягає в особливій економічній та соціальній природі банків, їх ролі в розвитку економіки країни. Регулювання банківської діяльності на міжнародному рівні пов'язане із глобалізаційними процесами фінансових ринків, особливими учасниками яких є банки. 


\section{Список літератури:}

1. Банківське регулювання і нагляд: методологія та практика : монографія / за ред. В.В. Коваленко. Одеса : Атлант, 2013. 492 с.

2. Лепинська І.О. Еволюція банківського регулювання та нагляду в Україні. Вісник Украӥнської академї̈ банківської справи. 2009. № 1 (26). С. 81-86.

3. Орлюк О.П. Банківська система України. Правові засади організації. Київ : Юрінком Інтер, 2003. $240 \mathrm{c}$.

4. Про банки і банківську діяльність : Закон України від 20.03.1991 р. № 872-XII. Відомості Верховної Ради УРСР. 1991. № 25. Ст. 281.

5. Про внесення змін та доповнень до Положення «Про порядок формування і розміри страхових фондів комерційних банків», затвердженого постановою Правління Національного банку України від 30.06 .95 p. № 167 : Постанова Правління Національного банку України від 31.01.1996 p. № 20. URL: http://zakon4.rada.gov.ua/laws/show/v0020500-96.

6. Про затвердження Положення про планування виїзних інспекцій і про порядок визначення та застосування комплексної рейтингової оцінки комерційних банків за системою CAMEL : Постанова Правління НБУ від 25.06.1998 р. № 246. (втратила чинність). URL: http://zakon4.rada.gov.ua/laws/show/ z0703-01.

7. Про Національний банк України : Закон України від 20.05.1999 p. № 679-XIV. Вiдомості Верховної Ради Украӥни. 1999. № 29. Ст. 238.

8. Про порядок видачі банкам ліцензії на здійснення банківських операцій : Постанова Правління НБУ від 06.05.1998 p. № 181. (втратила чинність). URL: http://zakon4.rada.gov.ua/laws/show/z0373-98.

9. Про порядок формування і розмір страхових фондів комерційних банків : Постанова НБУ № 167 від 30 червня 1995 року. (втратила чинність) URL: http://zakon4.rada.gov.ua/laws/show/v0020500-96.

10. Про систему гарантування вкладів фізичних осіб : Закон України від 23.02.2012 № 4452-VI. URL: https://zakon.rada.gov.ua/laws/show/4452-17\#Text.

11. Про фінансові послуги та державне регулювання ринків фінансових послуг : Закон України від 12.07.2001 р. Відомості Верховної Ради України. 2002. № 1. Ст. 1.

12. Про Фонд гарантування вкладів фізичних осіб : Закон України від 20.09.2001 р. № 2740-III. (втратив чинність). Відомості Верховної Ради України. 2002. № 5. Ст. 30.

\section{Khachaturian V.Kh., Khachaturian T.Kh. THE ORIGIN AND HISTORY OF LEGAL REGULATION OF BANKING IN UKRAINE}

The article is devoted to the research and development of banking since the Independence Day of Ukraine. The problem of strengthening and developing the banking system should always be the focus of the state and society, as their effective solution depends not only on the state of the banking sector, its ability to perform its unique functions, but also the stability and security of the financial system. Given the direct dependence of the financial system of the state on the banking system, it can be argued that in the global financial crisis, the issue of effective legal management of banking becomes especially relevant.

Regulation of banking is particularly specific, as it is presented as a process of establishing rules for banking activities in the order of legislative and other rule-making activities. Authorities of all branches of government control the National Bank of Ukraine, the latter monitors and supervises compliance with banking legislation by commercial banks and other non-bank financial institutions, applies coercion in case of violations of established rules of conduct along with the judiciary. The goals of public policy in the legal sphere define the goals of the system of public administration in this area as ensuring the stability and development of the state. It is through the history of development that we can come to the final conclusion.

Thus, this study is devoted to the study of the legal framework of the banking system of Ukraine. Consideration of the problems of formation and development of the banking system and its legal regulation is an extremely interesting and relevant topic.

The economic reform carried out in Ukraine is aimed at strengthening the foundation of the rule of law and civil society institutions. An organic component of this reform is banking reform, aimed at creating an efficient banking system, appropriate to the market economy, and adequate banking legislation. The state of the banking system is one of the most important indicators of the state of the entire economy of the country. The following stages of development of the banking system of Ukraine are accurately distinguished in scientific sources.

Key words: Law of Ukraine "On Banks and Banking", National Bank of Ukraine, banking system. 